\title{
ARTÍCULO ORIGINAL: Determination of ApoE gene in patients with mild cognitive impairment
}
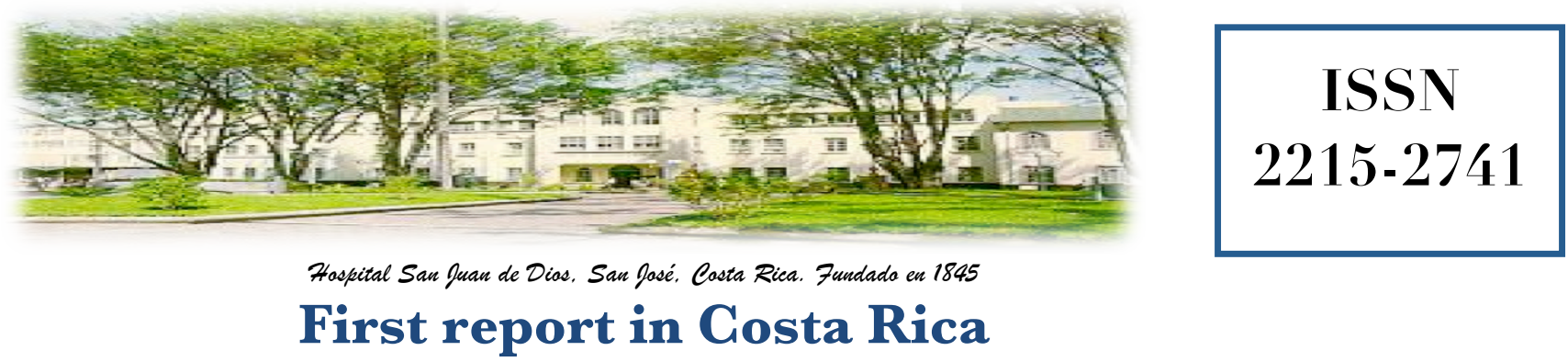

Recibido:

$26 / 03 / 2014$

Aceptado:

$21 / 04 / 2014$

\author{
Norbel Román Garita ${ }^{1}$ \\ Carolina Boza Calvo 2,5 \\ Leonardo Calvo Flores 3,5 \\ Alia Kozakova Valchuk ${ }^{4,5}$ \\ Adriana Von Storren Cortés ${ }^{4}$ \\ Luis Sequeira Rojas ${ }^{4}$
}

\footnotetext{
${ }^{1}$ Memory and Aging Clinic. Neurology Department. Hospital San Juan de Dios. E-mail: drnorbelroman@racsa.co.cr

${ }^{2}$ Centro de Investigación en Hematología y Trastornos Afines. Universidad de Costa Rica. Memory and Aging Clinic. Hospital San Juan de Dios. E-mail: cbozac@gmail.com

${ }^{3}$ Centro de Investigación en Hematología y Trastornos Afines, Universidad de Costa Rica. Hospital San Juan de Dios.

${ }^{4}$ Geriatrics and Gerontology Department. Hospital San Juan de Dios.

${ }^{5}$ Medical School, University of Costa Rica.
}

\section{RESUMEN}

Introducción: La enfermedad de Alzheimer (EA) es la causa más común de demencia. Es una enfermedad multifactorial en la que las condiciones genéticas y ambientales interactúan para presentar una manifestación clínica. El genotipo e4 de la apolipoproteína E (ApoE4) constituye un factor de riesgo para el desarrollo de la EA. Estimaciones indican que el alelo ApoE4 se presenta en el $15-16 \%$ de la población en general, con una mayor presencia en poblaciones caucásicas y casi en el $50 \%$ de los pacientes con EA. La presencia del genotipo de ApoE4 aumenta el riesgo de desarrollar EA de 3 a 8 veces más y disminuye la edad de aparición de la enfermedad entre 7 a 15 años antes. En forma homocigota el riesgo aumenta 33 veces. En pacientes de aparición tardía se encuentra en el $65 \%$ de los casos y el porcentaje se eleva al $80 \%$ cuando hay presencia de un familiar con EA. ApoE sigue siendo el biomarcador por excelencia para la predicción y el diagnóstico de EA. Objetivo: Estandarizar la técnica y determinar la frecuencia de ApoE en los 4 alelos de importancia clínica en los pacientes con deterioro cognitivo leve. Métodos: Se seleccionó una muestra de 14 pacientes previamente evaluados en la Clínica de Memoria y Envejecimiento del HSJD, diagnosticados con deterioro cognitivo leve amnésico. Se recogieron 
muestras de sangre y se realizó el protocolo de extracción de ADN de Miller et al. Posteriormente se realizó una PCR múltiple análisis simultáneo de los alelos de ApoE. Resultados: Se están analizando un total de 14 pacientes seleccionados según los criterios definidos por el equipo interdisciplinario, con el fin de determinar la presencia de los alelos de APOE en esta población. Conclusiones: La frecuencia de la presencia del gen ApoE permite describir las características de la población de Costa Rica como un factor de riesgo para el desarrollo de AD.

\section{PALABRAS CLAVE}

Apoliproteína E. ApoE4. Enfermedad Alzheimer. Deterioro cognitivo leve. Diagnóstico temprano. Biomarcador

\section{ABSTRACT}

Background: Alzheimer's disease (AD) is the most common cause of dementia. It is a multifactorial disease in which genetic and environmental conditions interact to present a clinical manifestation. The e4 genotype for the apolipoprotein $\mathrm{E}$ (ApoE4) is a risk factor for developing AD. ApoE4 presents $15-16 \%$ of the general population, with greater presence in Caucasian populations and nearly in $50 \%$ of subjects with AD. The presence of ApoE4 genotype increases the risk of developing AD 3 to 8 times higher and decreases age onset between 7 to 15 years. In homozygous form the risk increases 33 times. In late-onset $\mathrm{AD}$ is found in $65 \%$ of the cases and the percentage rises to $80 \%$ in presence of a family member with EA. ApoE remains the biomarker for predicting and diagnosing AD. Objective: To standardize the technique and determine the frequency of the ApoE's 4 alleles of clinical significance in patients with mild cognitive impairment. Methods: Patients who were previously evaluated in the Memory ClinicHospital San Juan de Dios and diagnosed with mild cognitive impairment were selected. We collected blood samples and performed DNA extraction protocol by Miller et al. Multiplex PCR was performed in 14 patients for the simultaneous analysis of gene ApoE genotype of the samples. Results: We are testing a total of 14 patients diagnosed with mild cognitive impairment who were previously diagnosed by the interdisciplinary team to determine the presence of the ApoE gene. Conclusions: The frequency of the presence of the ApoE gene allows to describe the characteristics of the Costa Rican population as a risk factor for developing $\mathrm{AD}$

\section{KEY WORDS}

Apoliprotein E. ApoE4. Alzheimer's disease, Mild Cognitive Impairment. Early diagnosis.

\section{BACKGROUND}

Alzheimer's disease (AD) is the most common cause of dementia. It is a multifactorial disease in which genetic and environmental conditions interact to present a clinical manifestation ${ }^{(1)}$. The e4 genotype for the apolipoprotein E (ApoE4) is a risk factor for developing AD. ApoE4 presents $15-16 \%$ of the general population ${ }^{(2)}$, with greater presence in Caucasian populations ${ }^{(3)}$ and nearly in $50 \%$ of subjects with AD. The presence of ApoE4 genotype increases the risk of developing AD 3 to 8 times higher and decreases age onset between 7 to 15 years $^{(4)}$. In homozygous form the risk increases 33 times $^{(2,5)}$. In late-onset $\mathrm{AD}$ is found in $65 \%$ of the cases ${ }^{(6,7)}$ and the percentage rises to $80 \%$ in presence of a family member with $\mathrm{EA}^{(8)}$. ApoE remains the biomarker for predicting and diagnosing $\mathrm{AD}^{(10)}$.

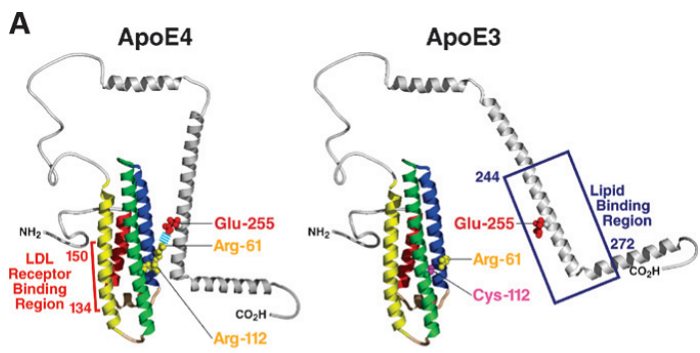

Figure 1. Structural protein conformation of the E4 and E3 haplotypes of ApoE

Source: http://biomodel.uah.es/model2/lip/apo-e4.htm

In Costa Rica, the first prevalence study conducted in a community (Santo Domingo de Heredia) with a sample of 400 subjects, showed a $4.2 \%$ prevalence of probable dementia (in any of its subtypes) ${ }^{(12)}$. Among the subjects evaluated 41 were diagnosed with $\mathrm{AD}(\mathrm{n}=14)$ and mild cognitive impairment (MCI, $\mathrm{n}=27$ ). 
At the Memory and Aging Clinic of the Hospital San Juan de Dios (CMEC) interdisciplinary diagnosis by consensus assessments have been conducted for the past 7 years, using a protocol established by the our team of neurologists, geriatricians and clinical psychologists, which includes a battery of tests for assessing cognitive and functional performance (screening, medical history, neuropsychological assessment, neurological examination, review of the patients record, molecular biology studies and neuroimaging).

In 2012 the CMEC reports a first analysis of the prevalence of $\mathrm{MCI}$ an $\mathrm{AD}$ in the population served by the clinic $(\mathrm{n}=128)$, during $2010-2011$. The most frequent diagnosis was MCI (44,5\%), while dementia were found in $30.5 \%$ of cases, where the $\mathrm{AD}(43,6 \%)$ and vascular dementia $(25,6 \%)$ predominated.

\section{Graphic 1. Final diagnosis}

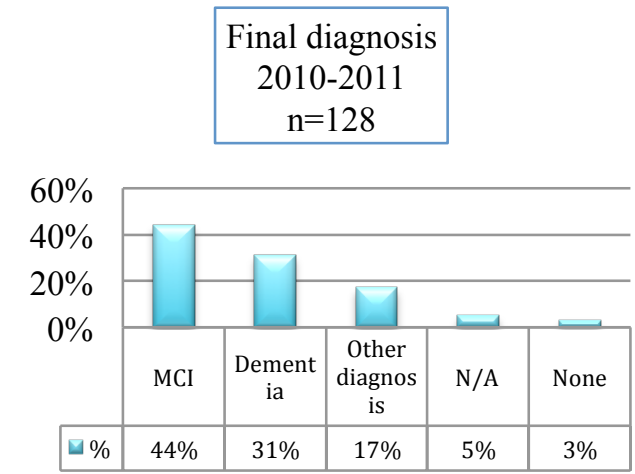

Source: Memory and Aging Clinic, HJSD.

These results showed that the CMEC is attracting patients at early stages, so our efforts should focus on this population. This highlights the importance of providing follow-up to patients and also reinforces the need to implement the detection of biomarkers and the presence of other genetic mutations considered as risk factors for dementia (ApoE), as a part of the diagnostic process. Thus, during 2012 there was a national campaign for early diagnosis, promoted by the Costarrican Alzheimer and Other Dementias Association (ASCADA), which gave the first donation of the ApoE detection kits.

The aim of this study is to standardize the technique for detection of the ApoE haplotypes in
DNA samples, and determine the frequency of the ApoE 4 alleles of clinical significance in patients with Amnesic Mild Cognitive Impairment (MCI-A), evaluated and diagnosed by the CMEC.

\section{METHODS AND MATERIALS}

Patients were previously evaluated in the Memory Clinic-Hospital San Juan de Dios using a protocol established by our team of neurologists, geriatricians and clinical psychologists, which includes a battery of tests for assessing cognitive and functional performance (screening, medical history, neuropsychological assessment, neurological examination, review of the patient's record, molecular biology studies and neuroimaging). Subjects gave written informed consent and the University of Costa Rica's institutional Bioethics review board approved the study. Patients diagnosed with MCI-A were randomly selected.

We collected blood samples and performed DNA extraction protocol by Miller et al, $1988^{(11)}$. Multiplex PCR was performed in 14 anonymous samples for the simultaneous analysis of gene ApoE genotype of the samples. PCR product ApoE was then analyzed by electrophoresis at $105 \mathrm{~V}$ for $35 \mathrm{~min}$ through a $2 \%$ agarose gel and stained with ethidium bromide.

\section{RESULTS}

We are testing a total of 14 anonymous samples of individuals diagnosed with MCI-A who were previously diagnosed by the interdisciplinary team to determine the presence of the ApoE gene. They were divided by according to amnesic MCI's subtypes (simple or multodomain).

Table 1. Distribution of Mild Cognitive Impairment (MCI) in patients previously evaluated in the Memory Clinic-Hospital San Juan de Dios $(n=14)$.

\begin{tabular}{c|c}
\hline MCI* $^{*}$ & Frequency \\
\hline MCI-Am & 71,43 \\
MCI-A & 28,57 \\
\hline
\end{tabular}

(*)MCI-Am: Amnestic multidomain MCI, MCI-A: Amnestic MCI. 
All of the samples were processed, but only fourth were able to determine their ApoE genotype. This due to a complex process of standardization that took longer than initially expected. The following are the preliminary results of the samples analyzed.

Table 2. Distribution of ApoE genotypes in patients previously evaluated in the Memory Clinic-Hospital San Juan de Dios $(n=14)$.

\begin{tabular}{|cc|}
\hline Genotype/Haplotypes & Frequency \\
\hline In process ${ }^{1}$ & 71,43 \\
\hline E3/E4 & 14,29 \\
\hline E3/E3 & 14,29 \\
\hline 112cys & \\
\hline Other $^{2}$ & 92,86 \\
\hline
\end{tabular}

1) Samples still not totally processed.

2) Protein conformation associated with E2 and E3 haplotypes.

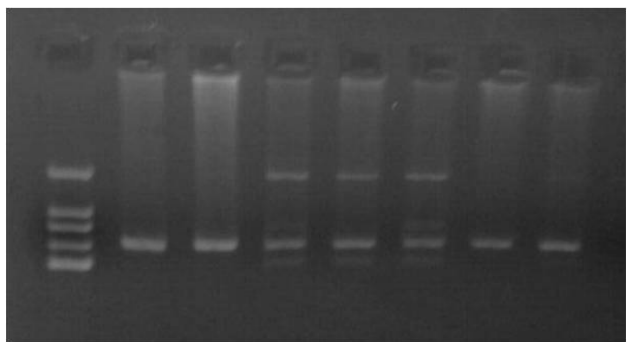

Figure 2. Multiplex PCR amplification of ApoE gene

\section{DISCUSSION AND CONCLUSIONS}

This is the first study of standardization of the test for ApoE genotype in Costa Rica. Despite the constraints faced, we now have solved the problems with the standardization of the technique and have the capacity to continue the analysis of the patients.

We overcome the most complicated stage for the application, which constituted the adaptation of the technique to our environment. This is a breakthrough because it is the stage that more time and resources involve.

Already achieved preliminary results of 4 samples of a new technique in the country, representing a pioneering project in our field, allowing it to provide the first results which will be statistically significant once more samples are processed.

\section{ACKNOWLEDGMENTS}

This article was possible by the support of Vicerrectoría de Investigación, Universidad de Costa Rica (project No. 807-B2-283) and Escuela de Medicina, Universidad de Costa Rica (project No. 422-B2-324).

\section{REFERENCIAS BIBLIOGRÁFICAS}

1. Román N Boza C. Revisión sobre la relación del genotipo para ApoE4 y el desarrollo de demencia tipo Alzheimer. Rev Cl EMed UCR. 2012;2(5). ISSN 2215-2741.

2. Salvia N Clarimon J. Genética en la Enfermedad de Alzheimer. Rev Neurol 2010;50(6):360- 364.

3. Crean S Ward A Mercald C et al. Apolipoprotein E 4: Prevalence in Alzheimer's disease patients varies across global population: A Systematic Literature Review and MetaAnalysis. Dement Geriatr Cogn Disord 2011;31:20-30.

4. Thambisetty M Beason H An Y Kraut MA Resnik SM. ApoE 4 Genotype and longitudinal changes in Cerebral Blood Flown in normal aging. Arch Neurol, 2010;67(1):93-98.

5. Anoop S Mirsa A Meena K Luthra K. Apolipoprotein E polymorphism in cerebrovascular and coronary heart disease. Indian J Med Res. 2010;363-378.

6. Reiman EM Long B Jessica BS Tariot PN. Alzheimer s prevention initiative: a proposal to evaluate presymptomatic treatment as quickly as possible. $\mathrm{Bi}-$ omark Med 2010;4(1):3-14.

7. Cruchaga C Kuwe J Mayo $\mathrm{K}$ et al. SNPs associated with cerebroespinal fluid phospho Tau levels influence rate of decline in Alzheimer Disease. En: www.plusgenetics.org. 2010;(6): Issue 9.

8. Dickstein D Walsh J Broutingam $\mathrm{H}$ Stockton S Gandy S Hof P. Role of vascular risk factors and vascular dysfunction in Alzheimer Disease. Mount Sinai Journal of Medicine. 2010;77:82-102. 
9. Thambisetty M Lovestone S. Blood based biomarkes of Alzheimer s Disease: Challenging but feasible. Biomark Med. 2010;4(1):65 -79.

10. Rothenberg K Lerner A Bonda D et al. Biomarhers in Alzheimer s Disease: past, present and future. Biomark 2010;4(1):15 -26.

11. Miller SA Dykes DD Polesky HF. A simple salting out procedure for extracting DNA from human nucleated cells. Nucl Acids Res. 1998;16:1215.

12. Steeland K Wesseling C Román N Quirós I Juncos JL. Occupational pesticide exposure and screening tests for neurodegenerative disease among an elderly population in Costa Rica. Environ Res (2012). Recuperado de http://dx.doi.org /10.1016/j.envres. 2012.08.014 